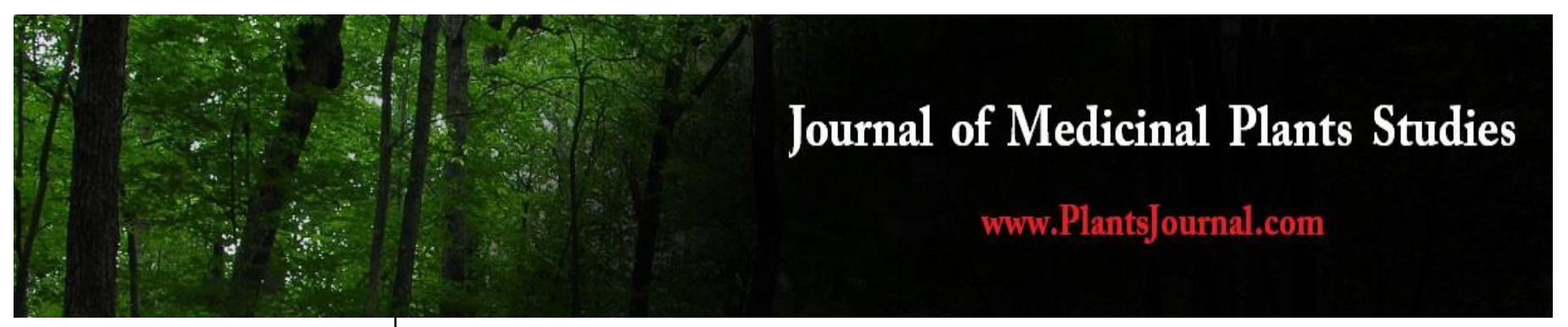

ISSN (E): 2320-3862

ISSN (P): 2394-0530

NAAS Rating: 3.53

www.plantsjournal.com

JMPS 2021; 9(3): 251-258

(C) 2021 JMPS

Received: 28-03-2021

Accepted: 30-04-2021

Subhashree Dash

Department of Botany, School of

Applied Sciences, Centurion

University of Technology and

Management, Odisha, India

Priyambada Monalisha Behera

Department of Botany, School of

Applied Sciences, Centurion

University of Technology and

Management, Odisha, India

Ushashee Mandal

Department of Botany, School of

Applied Sciences, Centurion

University of Technology and

Management, Odisha, India

Ruplin Nayak

Department of Botany, School of

Applied Sciences, Centurion

University of Technology and

Management, Odisha, India

\section{Sagarika Parida}

Department of Botany, School of

Applied Sciences, Centurion

University of Technology and

Management, Odisha, India

\section{Gyanranjan Mahalik}

Department of Botany, School of

Applied Sciences, Centurion

University of Technology and

Management, Odisha, India

Corresponding Author:

Gyanranjan Mahalik

Department of Botany, School of

Applied Sciences, Centurion

University of Technology and

Management, Odisha, India

\section{Potential medicinal plants of centurion university of technology and management, Bhubaneswar and their medicinal uses}

\author{
Subhashree Dash, Priyambada Monalisha Behera, Ushashee Mandal, \\ Ruplin Nayak, Sagarika Parida and Gyanranjan Mahalik
}

\section{DOI: https://doi.org/10.22271/plants.2021.v9.i3c.1303}

\section{Abstract}

Medicinal plants have long been important in the evolution of human society. Herbal medicines have always been at the forefront of practically all cultures or civilizations as a traditional remedy. Medicinal plants are considered rich sources of traditional remedies, and several modern medicines are derived from them. Medicinal plants have been used to treat illnesses, flavor and preserve food, and avert disease epidemics for thousands of years. The biological properties of plant species utilized all over the world are usually due to secondary metabolites produced by plants. Plant-derived compounds regulate microbial development in a variety of conditions. We provided a general overview of the medicinal plants that have been planted on our campus in this effort.

Keywords: disease, medicinal plants, microbial, secondary metabolites, traditional

\section{Introduction}

The term "Medicinal plants" denotes those non-aromatic and aromatic plants which are used for medicinal, perfumery, dye and cosmetic purpose. Spices and condiments also fall under this category ${ }^{[1]}$. Generally, the whole plant, flowers, leaves, fruits, stem roots or their bark, gums and oleoresins etc. are used. In India, the medicinal plants or herbs (the parts of the plant mostly dried) are used in (i) indigenous systems of medicine, i.e. Ayurvedic, Unani and Siddha; Tibetan system of medicine (mostly in border regions, i.e. Ladakh, Himachal Pradesh, Sikkim, etc. (ii) modern system of medicine; and (iii) homoeopathic system to some extent. From earliest times mankind has used plants in an attempt to cure diseases and relieve physical suffering. Primitive people in all ages have had some knowledge of medicinal plants, derived as the result of trial and error. These primitive attempts at medicine were based on speculation and superstition. Most savage people have believed that disease was due to the presence of evil spirits in the body and could be driven out only by the use of poisonous or disagreeable substances calculated to make the body an unpleasant place in which to remain ${ }^{[2]}$. India has a long history on the use of a large number of medicinal plants for various purposes. The history of medicine in India can be traced to the remote past. The earliest mention of the medicinal use of plants is found in the Rig Veda, perhaps the oldest repository of human knowledge, having been written between 4500 and 1600 B.C. The work of Agnivesha resulted in the compilation of Charaka-Samhita by Charaka. Sushruta a brilliant disciple of Dhanvantri, was known for his knowledge of surgery and medicine ${ }^{[3]}$.

It is roughly estimated that about 350 medicinal plants are collected from the wild sources in the country and used for various purposes. Many are those which have been collected from time immemorial and in recent years the pressure is so high that many have become vulnerable. Medicinal Plants are used in folk medicines by various tribal and ethnic groups in India ${ }^{[4]}$

Pharmacies (covering the modern, indigenous and homoeopathic systems) in the country using the medicinal plants and now the number may have increased to 50,000 ${ }^{[5]}$. Besides, it is estimated that there are about 4,000 indigenous and modern perfumeries that manufacture and blend the scents and 'attar' from natural oils derived from wild growing or cultivated aromatic plants ${ }^{[6,7]}$. 
The World Health Organization has estimated that at least $25 \%$ of all allopathic medicines contain a plant derivative. Many modern medicines have their origin from medicinal plants examples includes aspirin from willow bark (Salix sps.), digitalis from foxglove (Digitalis purpurea) and vinblastine from periwinkle or sadabahar (Vinca rosea), Ephedra (source of ephedrine), Rauwolfia or sarpgandha (source of reserpine), Commiphora guggul (source of drug gugulipid), Atropa (source of drug atropine) etc. ${ }^{[8,9]}$. Based on clinical effects 50 categories of drug have been described in traditional ayurvedic medicine, such as appetizers, digestive stimulant, laxatives, anti-diarrhea, anti-hemorrhoid, anti-emetic, anti-pyretic, anti-inflammatory, antipruritic, antiasthmatic, antiepileptic, anti-helminthic, haemoptietic, haemostatic, analgesic, sedative, promoter of life (Rasyana), promoter of strength, complexion, voice, semen and sperm, breast milk secretion, fracture and wound healing, destroyer of kidney stones etc. ${ }^{[10]}$. Drugs are obtained from different parts of plants like from fruits (Senna, Datura etc.), flowers (Dhak, Kachnaar), leaves (Senna, Datura, Periwinkle, Tylophora etc.), stems (Liquorice, Ginger, Dioscorea, Garlic), roots (Rauwolfia, Periwinkle, Gineseng etc.), seeds (Isabgol, Abrus, Nuxvomica) and even from bark (Cinchona) [11].

The World Health Organization defined health Education as comprising of consciously constructed opportunities for learning involving some form of communication designed to improve health literacy, including improving knowledge, and developing life skills which are conducive to individual and community health. Thus educating people and making them aware about health problems related to lifestyle and dietary change can help them to ease the burden of health care cost which is increasing day by day. Besides this medicinal use of common herbal pant resources can also fulfill the same target [12].

Growing interest in traditional, complementary and alternative medicine (TCAM) and its relevance in public health both in developed and developing countries in the recent past has provided an option for use of ethno-medicinal plant resources. Considering the adverse effects of synthetic drugs the Western population is looking for natural remedies which are safe and effective. Diversity, flexibility, easy accessibility, broad continuing acceptance in developing countries and increasing popularity in developed countries, relative low cost, low levels of technological input, relative low side effects and growing economic importance are some of the positive features of traditional medicine. Alternative medicines are considered to be effective in chronic, acute and lifestyle diseases ${ }^{[13]}$.

\section{Enumeration of plants ${ }^{[14-24]}$}

Allium cepa L.

Family: Amaryllidaceae

Hindi name: Palandu, Piyaj

Other names: Bulb onion, Garden onion, White onion

\section{Morphological characteristics of onion}

It is Biennial or perennial. Leaves arise from underground part of the stem. The common onion has one or more leafless flower stalks that reach a height of 75-180 cm (2.5-6 feet). Inflorescence of onion is called cume. Each individual flower is made up of six stamens, three carpels, united with one pistil and six perianth segments. The pistil contains three locules, each containing two ovules.

\section{Medicinal uses}

- Onions as medicine help treating high cholesterol, diabetes, joint disorders, digestive ailments, loss of appetite, gallbladder diseases, angina pectoris, high blood pressure, atherosclerosis, sore throat, asthma, bronchitis, cough, intestinal gas and intestinal worms' onions. The main active constituent in onions is quercetin, which is one of flavonoid that exhibits a good antioxidant property. Another phytochemical is Allyl sulfide. It also possesses for antioxidants, Anti-inflammatory, Anticholesterol, Anti-hypertensive, Anti- cancer, Antiarthritic, Anti-bacterial or Anti-biotic, Bronchodilator, Expectorant, Anti- spasmodic, Antiseptic, Carminative, Anti-coagulant, Fibrinolytic and Anthelmintic properties.

- Onions have mild anti-asthmatic and potent antiinflammatory effects. However, onions cannot be used for therapeutic purposes in bronchitis and asthma, but it can be a good diet for patients with bronchitis and asthma. For asthma, a mixture of onion juice, honey and black pepper is useful. It reduces chest congestion, wheezing and gives relief from breathing difficulties. Onions are rich in potassium, fiber, sulfur, Vitamin C, Vitamin B. They are low in fat, sodium and cholesterol. Due to their medicinal properties, onions can help curing common cold, fever, sore throat, cough, allergies and many more.

- Onions have antiseptic, anti- biotic, carminative and antimicrobial properties, which help in staying away from different kinds of infections. Onions active constituents inhibit bacterial growth and are effective against both types of bacteria gram-positive and gramnegative. A mixture of onion juice along with honey can help in common cold.

Azadirachta indica A. Juss

Family: Mahogany

Common name: Neem

Others: Nimba, Nim tree, Neem, Margosa, Indian-lilac, Bemba Mara

\section{Morphological characteristics}

Evergreen trees, to $20 \mathrm{~m}$; bark greyish-brown, vertically striated; exudation red, sticky. Leaves imparipinnate, alternate, estipulate; rachis 14-30 cm long, slender, swollen at base, glabrous, leaflets 7-15, opposite or sub opposite, estipellate; petiolule 3-5 mm long, slender, glabrous; Flowers's bisexual, $8 \mathrm{~mm}$ across, white, in axillary panicles; bracteoles scaly; pedicel $5 \mathrm{~mm}$; sepals 5 , connate at base, ovate, margin ciliate; petals 5 , free, white, oblong-obovate, pubescent, spreading, imbricate; staminal tube $4 \mathrm{~mm}$ long, glabrous, apically 10 lobed; lobes truncate; anthers 10, slightly exserted, apiculate, opposite to lobes, sessile; ovary superior, globose, 3-celled; ovules 2 per cell; style slender, elongate; stigma terete, 3-lobed. Fruit a drupe, $1.5 \times 0.5 \mathrm{~cm}$, oblong-ovoid, greenish-yellow.

\section{Medicinal uses}

- Neem is a tree. The bark, leaves, and seeds are used to make medicine. Less frequently, the root, flower, and fruit are also used. Neem leaf is used for leprosy, eye disorders, bloody nose, intestinal worms, stomach upset, loss of appetite, skin ulcers, diseases of the heart and blood vessels (cardiovascular disease), fever, diabetes, gum disease (gingivitis), and liver problems. The leaf is also used for birth control and to cause abortions. 
- The bark is used for malaria, stomach and intestinal ulcers, skin diseases, pain, and fever. The flower is used for reducing bile, controlling phlegm, and treating intestinal worms. The fruit is used for hemorrhoids, intestinal worms, urinary tract disorders, bloody nose, phlegm, eye disorders, diabetes, wounds, and leprosy. Neem twigs are used for cough, asthma, hemorrhoids, intestinal worms, low sperm levels, urinary disorders, and diabetes. People in the tropics sometimes chew neem twigs instead of using toothbrushes, but this can cause illness; neem twigs are often contaminated with fungi within 2 weeks of harvest and should be avoided. The seed and seed oil are used for leprosy and intestinal worms. They are also used for birth control and to cause abortions. The stem, root bark, and fruit are used as a tonic and astringent.

Basella rubra L.

Family: Basellaceae

Common name: Indian spinach, Malabar spinach, Indian spinach, Ceylon spinach, Vine spinach

\section{Morphological characteristics}

Succulent glabrous herb becoming a slender, twining vine, the stems at first stout, to $2 \mathrm{~cm}$ thick, green, after several months of growth and attaining height of 15-45 cm, narrowing, sometimes abruptly and becoming slender, elongate and climbing. Leaves sessile or short petiolate, $4-7 \mathrm{~cm}$ long, entire, fleshy, ovate, often broadly so, the juvenile leaves often larger, apically rounded, obtuse or acute, basally cuneate, truncate, or cordate, the lateral venation somewhat obscure, ca. Flowers perfect, sepals white, pink, or red, 3-5 $\mathrm{mm}$ long, united to above the middle, urceolate to cylindrical, the 5 lobes broad, short, cucullate; stamens included, inserted at the base of the perianth lobes, the filaments short, the anthers cordate, included; ovary conical, l-locular, sometimes partitioned, the 3 styles slender, papillose pilose.

\section{Medicinal uses \\ Leaves of Malabar spinach are chewed raw to treat mouth ulcers. Decoction of leaves helps to relieve constipation in children and pregnant women. Leaves are crushed and applied locally in bruises, wounds, scalds, burns, boils, snakebites, pimples etc. It relieves burning sensation and inflammation. To increase fertility in women, it is used along with hibiscus macaranthus. The decoction of roots relieves bilious vomiting. The root paste is applied on swellings and also used to relieve inflammation. Cooked roots are used to treat diarrhoea.}

\section{Breynia retusa (Dennst.) Alston \\ Family: Phyllanthaceae \\ Common name: Cup Saucer Plant \\ Other name: Ekdania, Mulluvenga, Cup Saucer Plant, Kangli, Cupped Coral-berry}

\section{Morphological characteristics}

Shrubs, 1-1.5 m high. Leaves 1.3-2.5 x 0.7-1.3 cm, broadly elliptic or ovate, base rounded or acute, apex obtuse, glaucous below, black on drying; petiole to $2 \mathrm{~mm}$ long. Flowers unisexual, solitary, axillary. Male flowers c. $3 \mathrm{~mm}$ across; pedicels c. $1 \mathrm{~mm}$ long; perianth turbinate, 3-4 mm long, truncate; lobes 5-6; stamens 3. Female flowers 5-6 mm across; pedicels 3-4 mm; perianth campanulate, 3-4 mm long, 5-6-lobed.

\section{Medicinal uses}

Breynia retusa reveals for its dysentery, toothache, skin inflammation, hyperglycemia, diarrhoea and as astringent and diuretic, anti-arthritic effect. B. retusa leaf juice is used to cure body pain, skin inflammation, hyperglycaemia, diarrhoea and diuretic. The fruits have been used for dysentery and twigs used for toothache. The anti-diabetic effect of B. retusa. Traditional medicament plays an important role in our day-today life in spite of overwhelming influence of modern medicine in treatment of various disorders like diabetes, viral infection, rheumatic disease, allergic condition, obesity, respiratory diseases, cardiovascular diseases, etc.

\section{Lawsonia inermis L. \\ Family: Lythraceae \\ Common name: Henna \\ Other names: Mehendi, Hena pambi, Marudaani, Goranti}

\section{Morphological characteristics}

Lawsonia inermis is a glabrous branched shrub or small tree. Leaves are small, opposite, entire margin elliptical to broadly lanceolate, sub-sessile, about 1.5 to $5 \mathrm{~cm}$ long, 0.5 to $2 \mathrm{~cm}$ wide, greenish brown to dull green, petiole short and glabrous acute or obtuse apex with tapering base. New branches are green in colour and quadrangular, turn red with age. Flowers are small, numerous, aromatic, white or red coloured with four crumbled petals. Calyx has $0.2 \mathrm{~cm}$ tube and $0.3 \mathrm{~cm}$ spread lobes.

\section{Medicinal uses}

Henna has at times been used in traditional medicine as a remedy against almost any disease, much of this probably being based on the high regard the plant is held in rather than any actual benefits. However, the plant does contain a range of medically active substances including coumarins, naphthoquinones (Including lawsone), flavonoids, sterols and tannins, and is known to be of benefit in a range of conditions. It is an astringent herb with a tea-like aroma, that controls bleeding and is antibacterial. It is regarded as an alternative and nerve tonic in Ayurvedic medicine. The leaves are taken internally in the treatment of amoebic dysentery. They are also used in the treatment of diarrhoea and to promote menstrual flow. They are used as a gargle to treat sore throats. Extracts of the leaves have an astringent effect on the skin, making it somewhat hydrophobic. This effect, combined with a slight bactericidal and fungicidal action, makes it a useful medicine for external uses against many skin and nail complaints. The leaves are, therefore, used externally in the treatment of various skin diseases (including leprosy), wounds, ulcers and herpes. A decoction of the bark is used as an emmenagogue, and also to treat liver problems and nervous symptoms. The stem bark is chewed and then kept between the teeth for about 25 minutes in order to treat toothache.

\section{Terminalia bellirica (Gaertn.) Roxb.}

Family: Combretaceae

Common name: Bahada

Oriya: Bahada

Others: Thani, Beach Almond, Belliric Myrabolan, Bastard Myrobalan

\section{Morphological characteristics}

Deciduous trees, to $35 \mathrm{~m}$ high, bole often buttressed; bark 10$20 \mathrm{~mm}$ thick, surface blackish-grey, smooth, vertically 
shallowly fissured, exfoliations small, semi-fibrous; blaze yellow; branches sympodial; branchlets terete, thinly fulvoushairy, leaf scars prominent. Leaves simple, opposite or alternate, clustered at the tip of branchlets, estipulate; petiole $15-80 \mathrm{~mm}$, stout, slightly grooved above, glabrous; Flowers's bisexual, greenish- yellow, 5-6 mm across, in axillary spikes; peduncle puberulous; bracteoles $0.5-2 \mathrm{~mm}$ long, linearlanceolate, caducous; calyx tube $2-2.5 \times 1.3-2 \mathrm{~mm}$, rusty pubescent, constricted above the ovary; lobes 5, cream, triangular, tomentose; disc 5-lobed, villous; petals absent; ovary $1.5 \mathrm{~mm}$, inferior, tomentose, 1-celled; ovules 2 or 3 , pendulous; style $4 \mathrm{~mm}$, subulate; stigma small.

\section{Medicinal uses}

Baheda has been mentioned in several ayurvedic scriptures and journals for various indications which include Jvara (useful in fever), Kasahara (Relieves cough), Amahara (treats indigestion), Dahahara (relieves burning sensation), Shwasha (relieves breathing difficulties), Deepana (enhances stomach fire), Pachana (helps in digestion), Rochana (stimulates appetite), Anulomana (improves breathing), Vayasthapana (prevents ageing), onitasthapana (prevents bleeding), Sangrahini (treats diarrhoea), Kustha (treats skin disorders), Kamala (prevents jaundice), Raktadoshahara (blood purifying), Vran Ropana (heals wounds), Mehahara (treats urinary tract disorders), Prameha (manages diabetes), Vamana (prevents nausea and vomiting), Trutahara (relieves excessive thirst), Balya (improves muscle strength), Hikkanigrahana (controls hiccups), Kantya (relieves sore throat), Triptighno (relieves pseudo-satiation), and Vamanopaga (treats emesis), Varnya (improves complexion), Krimihara (relieves intestinal worms), Hridaya (treats heart problems), and Kanthya (improves voice). The anti-inflammatory and anti-ulcer properties of Baheda hold high significance in treating different types of ulcers like ulcerative colitis, peptic ulcer, canker sores or mouth ulcers, etc. The bioactive compounds in the fruit powder actively enhances tissue regeneration, facilitates wound healing whereas the oil extracted from the seeds is also used for dressing wounds.

\section{Phyllanthus emblica L.}

Family: Phyllanthaceae

Common name: Amla

Others: Nelli, Amalo, Sinhlu

\section{Morphological characteristics}

A small deciduous tree to $15 \mathrm{~m}$ high, bark grey-brown, rough, irregularly flaking; blaze pink- red. Leaves simple, alternate, bifarious on short deciduous branchlets, closely overlapping, subsessile; stipules minute, lateral, linear; lamina 0.4-1.5 x 2$4 \mathrm{~mm}$, oblong or linear-oblong, base round, apex obtuse and shortly apiculate, glabrous, membranous; nerves obscure. Flowers unisexual, 2-3 mm across, greenish-yellow, densely clustered in leaf axils; male flowers: tepals 6, oblanceolate, $1.5 \mathrm{~mm}$, obtuse, stamens 3 , anthers oblong, connate by their connectives; apiculate; disc glands 6; female flowers: tepals 6, oblanceolate, obtuse; ovary superior, $1.5 \mathrm{~mm}$, 3-celled; ovules 2 in each cell; styles 3 , broadly fimbriate, recurved, stigma tiferous.

\section{Medicinal uses}

Amla protects cells against free radical damage and provides antioxidant protection. Amla is used to treat skin disorders, respiratory infections, and premature aging. Amla is useful in hemorrhage, diarrhoea, dysentery, and has therapeutic value in treating diabetes. Amla has antibacterial and astringent properties that help to prevent infection and help in the healing of ulcers. Amla is sometimes used as a laxative to relieve constipation in piles. Indian gooseberry is beneficial in the treatment of respiratory disorders. It is especially valuable in tuberculosis of lungs asthma and bronchitis. The juice of Indian gooseberry with honey is useful in preserving eyesight. It is beneficial in the treatment of conjunctivitis and glaucoma. It reduces intraocular tension in a remarkable manner. Juice mixed with honey can be taken twice daily for this condition.

Strychnos nux-vomica L.

Family: Loganiaceae

Common name: Kuchla

Other name: Visamusti, Kuchila

\section{Morphological characteristics}

Strychnos species is a medium-sized, deciduous tree, with fairly straight and cylindrical bole and dark-grey or yellowishgrey bark with minute tubercles. Leaves are simple, opposite, orbicular to ovate, $6-12 \mathrm{~cm}$ long and $6-10 \mathrm{~cm}$ broad, coriaceous, glabrous, and five-nerved. Flowers of Kuchila are white or greenish white and fragrant. They occur in many flowered terminal cymes. Calyx is five lobed, pubescent, and small, about $2 \mathrm{~mm}$ in size, while corolla is salver shaped and has five lobes.

\section{Medicinal uses}

Kuchla is used to treat many different conditions. These include: digestive problems such as constipation, bloating, heartburn, and nausea. Male infertility and impotence. Colds and flus, particularly in the early stages of the virus, allergies, back pain, irritability, impatience, and high sensitivity to stimuli, caused by stress or mental strain, headaches and migraines symptoms such as a sore scalp, frontal pain, light sensitivity, or stomach problems, hangovers, menstrual problems and insomnia. It is also used for nerve conditions, depression, migraine headache, symptoms of menopause, and a blood vessel disorder called Raynaud's disease.

Aloe vera (L.) Burm. f.

Family: Asphodelaceae

Common name: Ghrit Kumari

\section{Morphological characteristics}

Aloe vera is a hardy succulent plant that thrives in poor soils and requires little water to survive and spread. This species produces dense rosettes with creeping rhizomes that easily spread from basal offshoots colonizing extensive areas and outcompeting and displacing other species including native vegetation. Leaves sub-basal, slightly distichous in seedlings and new shoots, erect, pale green, sometimes with pale spots in very young plants, linear-lanceolate, 15-35(-50) $\times 4-5(-7)$ $\mathrm{cm}$, margin sparsely spiny-dentate, apex 2- or 3-dentatepointed. Inflorescence erect, $60-90 \mathrm{~cm}$; peduncle to $2 \mathrm{~cm}$ thick; raceme $30-40 \times 5-6 \mathrm{~cm}$, sometimes with 1 or 2 ascending branches, numerous flowered; bracts whitish, broadly lanceolate, $10 \times 5-6 \mathrm{~mm}$, veins $5-7$, apex acute. Flowers reflexed; pedicel $1 / 2$ as long as bract.

\section{Medicinal uses \\ Improves digestive health}

Consuming Aloe vera may benefit your digestive tract and help to soothe and cure stomach ailments, including irritable bowel syndrome. 


\section{Relieves anal fissures}

If you have anal fissures, applying an Aloe vera cream to the affected area several times throughout the day may help promote healing. Source found that using a cream containing Aloe vera juice powder was effective in treating chronic anal fissures. People used the Aloe cream three times a day for six weeks.

\section{Heals burns}

Due to its soothing, moisturizing, and cooling properties, Aloe vera is often used to treat burns. Aloe gel can be beneficial for burn wound healing.

Asparagus racemosus Willd.

Family: Asparagaceae

Common name: Satavar, Shatavari, or Shatamull, Shatawari

\section{Morphological characteristics}

Asparagus racemosus is a climber having stems up to $4 \mathrm{~m}$ long. Its roots are both fibrous and tuberous. Shatavari has small pine-needle-like phylloclades (photosynthetic branches) that are Aloe September it fruits, producing blackish-purple, globular berries. It has an adventitious root system with tuberous roots that measure about one metre in length, tapering at both ends, with roughly a hundred on each plant. It grows $1-2 \mathrm{~m}$ ( $3 \mathrm{ft} 3$ in- $6 \mathrm{ft} 7 \mathrm{in}$ ) tall and prefers to take root in gravelly, rocky soils high up in piedmont plains, at 1,300$1,400 \mathrm{~m}(4,300--4,600 \mathrm{ft})$ elevation.

\section{Medicinal uses}

Shatavari is important in traditional Ayurvedic medicine. Dried root extracts are used for various reproductive and hormonal problems in women. They are also used for stomach ulcers and indigestion.

\section{Improving women's reproductive health}

Probably the most common traditional use of shatavari, or $A$. racemosus, is for the treatment of women's health, especially reproductive disorders source suggests that this plant may improve conditions such as hormonal imbalance and polycystic ovary syndrome. Consistent with its traditional use as a treatment for female reproductive conditions, recent research suggests that a combination of herbal medicinal products, including $A$. racemosus, may reduce the symptoms of menopause.

\section{Zingiber officinale Rosc. \\ Family: Zingiberaceae \\ Common name: Adrack}

\section{Morphological characteristics}

Erect, slender, perennial herb usually grown as an annual crop, with a thickened, fleshy, subterranean rhizome and with one or more aerial leafy stems, up to $1.25 \mathrm{~m}$ tall. Stem erect, unbranched, mainly formed by the leaf sheaths, pale green, often reddish at base; scales covering the lower part oblong, about $6 \mathrm{~cm} \times 1 \mathrm{~cm}$, scarcely white-pilose outside, with prominent parallel veins and scarious margins. Inflorescence arises direct from rhizome, spiciform, $15-30 \mathrm{~cm}$ long; scape slender, 10-20 cm long, below the spike covered with scales as on the leafy stem bases, the upper ones sometimes with short leafy tips; calyx tubular-spathaceous, 10-12 mm long, whitish; corolla tubular, pale yellow, widening at top into 3 lobes, tube 18-25 mm long, dorsal lobe long ovate, 15-25 mm $\mathrm{x} 7-8 \mathrm{~mm}$, with beak-like rounded apex curved over the anther, ventral lobes oblong, 13-15 mm x 2-3 mm, apex rounded, 3-veined, strongly recurved; labellum about circular in outline, $12-15 \mathrm{~mm}$ in diameter, tubular at base, 3-lobed above; central lobe obovate.

\section{Medicinal uses}

Ginger has a very long history of use in various forms of traditional and alternative medicine. It's been used to aid digestion, reduce nausea, and help fight the flu and common cold, to name a few of its purposes.

\section{Can treat many forms of nausea, especially morning sickness}

Ginger appears to be highly effective against nausea. It may help relieve nausea and vomiting for people undergoing certain types of surgery. Ginger may also help chemotherapyrelated nausea, but larger human studies are needed. However, it may be the most effective when it comes to pregnancy-related nausea, such as morning sickness.

\section{Can help with osteoarthritis}

Osteoarthritis is a common health problem. It involves degeneration of the joints in the body, leading to symptoms such as joint pain and stiffness. Only mild side effects, such as dissatisfaction with the taste of ginger, were observed. However, the taste of ginger, along with stomach upset, still prompted nearly $22 \%$ of the study participants to drop out. A majority of them had been diagnosed with OA of the knee.

Saraca asoca (Roxb.) WIlld.

Family: Fabaceae

Common name: Asoka

\section{Morphological characteristics}

Saraca asoca is a medium-sized, evergreen tree with beautiful fragrant flowers. Leaves are alternate, paripinnate, copper red when young and green when mature, and 30-60 cm long. Bark on old stems is dark green in colour, often marked by bluish and ash white patches of lichens. Fragrant flowers are orange or orange yellow in colour. Fruit is a four to eight seeded, flat and black coloured, leathery pod.

\section{Medicinal uses}

- Stem bark of Asoka tree is strongly astringent and a uterine sedative, uterine tonic, and styptic, having a stimulating effect on endometrial and ovarian tissue. It has a strong effect upon the uterine muscles, and is especially useful in the treatment of uterine hemorrhages, menstrual cramps, menorrhagia and leucorrhea.

- An extract of the flowers is useful in the treatment of hemorrhoids and dysentery. The flowers are also useful in the treatment of scabies in children and various other skin diseases. The seeds are used in the treatment of urinary discharges various studies have been carried out on the medicinal actions of this plant. The plant has been shown to stimulate the endometrial and ovarian tissue, and to be useful in treating disorders such as menorrhagia, dysmenorrhea, premenstrual syndrome, abnormal bleeding and threatened abortion.

Tamarindus indica L.

Family: Fabaceae

Common name: Tamarind

\section{Morphological characteristics}

Tamarindus indica is a long lived and beautiful fruiting tree, growing up to 30 meters tall with a dense, spreading crown. 
The tree has fragrant flowers and feathery foliage that is usually evergreen but becomes deciduous in drier regions. The bowl is usually short, $1-2$ meters in diameter. The seedpod of the tamarind is widely used for food in the tropics. The tree also yields a number of other edible uses, as well as having a wide range of medicinal applications and other uses. The tree is widely cultivated in the tropics and subtropics as an ornamental plant, for its edible seedpods and also for its many medicinal uses.

\section{Medicinal uses}

- The bark is astringent and tonic and its ash may be given internally as a digestive. Incorporated into lotions or poultices, the bark may be used to relives sores, ulcers, boils and rashes. It may also be administered as a decoction against asthma and amenorrhea and as a febrifuge.

- Leaf extracts exhibit anti-oxidant activity in the liver, and are a common ingredient in cardiac and blood sugar reducing medicines Young leaves may be used in fomentation for rheumatism, applied to sores and wounds, or administered as a poultice for inflammation of joints to reduce swelling and relieve pain. A sweetened decoction of the leaves is good against throat infection, cough, fever, and even intestinal worms.

- A decoction of the flower buds is used as a remedy for children's bedwetting and urinary complaints.

- The fruit is aperients and laxative. Syrup made from the ripe fruit is drunk in order to keep the digestive organs in good condition, and also as a remedy for coughs and chest colds. The flesh of the fruit is eaten to cure fevers and control gastric acid. The fruit pulp may be used as a massage to treat rheumatism, as an acid refrigerant, a mild laxative and also to treat scurvy powdered seeds may be given to cure dysentery and diarrhoea.

Tridax procumbens L.

Family: Asteraceae

Common name: Bikhalyakarani, Coatbuttons or Tridax daisy

\section{Morphological characteristics}

Inflorescences in solitary capitulum, held by a peduncle, 12 to $32 \mathrm{~cm}$ long, abundantly hispid. The bracts of the involucre are arranged in 2 rows. They are oval to lanceolate; $6 \mathrm{~mm}$ long, pubescent and green. Flower is Capitulum formed of 3 to 8 ligulate daisy like female flowers, creamy white on the periphery of capitulum, tridentate. In the center of capitulum, flowers are yellow, tubulate bisexual. The tube, $6 \mathrm{~mm}$ long, with five short tines at the top. This plant has two types of the flower as ray florets and disc florets with basal placentation. Stem is cylindrical, hispid, covered with multi-cellular hairs of $1 \mathrm{~mm}$; tuberculation at the base.

\section{Medicinal uses}

- T. procumbens can be used for wound healing, staunching bleeding and treatment of diarrhoea, backache and bronchial catarrh.

- Essential oils extracted from T. procumbens are reported to have insecticidal activity against Musca domestica, Culex quinque fasciatus, Dysdercus similis and Supella spp.

Calotropis gigantean (L.) W.T. Aiton.

Family: Apocynaceae

Common name: Crown flower or giant milkweed

\section{Morphological characteristics}

A large shrub, much branched, gregarious, young branches covered with white, cottony hairs, contains milky latex. Stem is Erect, branched, cylindrical, solid, contains milky latex. Leaves is 4-8 inches long, decussate, obovate or ellipticoblong, shortly acute, subsessile, cordate or often amp lexical at the base. Flowers are Large, white, not scented, peduncles arising between the petioles. Flower-buds ovoid, angled, Calyx lobes 5, divided to the base, white, ovate; corolla broadly rotate, valvate, lobes 5, deltoid ovate, reflexed, coronate-appendages broad, obtusely 2 -auricled below the rounded apex which is lower than the staminal-column. Stamens 5, anthers short with membranous appendages, inflexed over the depressed apex of the pentagonal stigma. Carpels 2 distinct, styles 2 , united to the single pentagular stigma, ovary 2-celled, ovules many.

\section{Medicinal uses}

- People use the bark and root bark for medicine. Calotropis is used for digestive disorders including diarrhoea, constipation and stomach ulcers; for painful conditions including toothache, cramps, and joint pain; and for parasitic infections including elephantiasis and worms.

- Some people use Calotropis for syphilis, boils, inflammation (swelling), epilepsy, hysteria, fever, muscular spasm, warts, leprosy, gout, snakebites, and cancer.

- In inhalation therapy, smoke from the bark is inhaled for coughs, asthma, and to cause sweating.

- Calotropis has shown some activity against pain, inflammation, bacteria, fever, and ulcers caused by alcohol and medications such as aspirin, indomethacin (Indocin), and others.

Santalum album L.

Family: Santalaceae

Common name: Sandalwood, Chandan

\section{Morphological characteristics}

Evergreen trees, to $10 \mathrm{~m}$ high, bark surface dark grey to nearly black, rough with short vertical cracks. Leaves simple, opposite, estipulate; petiole 12-18 mm long, slender, glabrous, grooved above; lamina 3.7-12 x 2-4 cm, elliptic, elliptic-ovate or ovate-lanceolate, base acute or round, apex acute, margin entire, glabrous, shiny above and glaucous beneath, coriaceous; lateral nerves 8-13 pairs, pinnate, faint, intercostal reticulate, obscure. Flowers bisexual, 5-6 mm across, reddishpurple, in axillary and terminal paniculate cymes, much shorter than leaves; tepals 5, basally connate into a campanulate tube of $2 \mathrm{~mm}$ long, shortly connate to the basal part of the ovary; lobes $2.5 \times 1.5 \mathrm{~mm}$, ovate, thin, fleshy, glaucescent without, minutely ciliate; stamens 5, alternates with disc; filaments $1 \mathrm{~mm}$; anthers $0.7 \mathrm{~mm}$, ovoid, 2-celled; ovary superior later half inferior at the time of flowering, globose, $1 \mathrm{~mm}$, 1-celled, ovules 2-3, pendulous from below the long, acuminate, central column.

\section{Medicinal uses}

- Sandalwood oil has many traditional uses. For centuries, East Indian sandalwood oil has been a popular ingredient in Ayurvedic medicine, the folk medicine of India. In these traditions, sandalwood oil has been used with other therapies to manage: the common cold, urinary tract infections, muscle problems, scabies, hemorrhoids. 


\section{- Skin cancer}

A study reported in the Archives of Biochemistry and Biophysics suggests a compound found in sandalwood oil may help fight skin cancer. That compound is called $\alpha-$ santalol. Some studies have shown that this component can help promote skin cell.

\section{Conclusion}

This above research shows that Plant based medicines have less side effect and can be used almost all types of diseases like fungal, bacterial and somehow viral, traditional Indian medicine (Ayurveda) is becoming increasingly popular, with many chronic conditions responding to it well. Each and individual plants have some medicinal property whether it's a herb, shrub, tree or a grass. Most patients begin to take conventional medications as soon as their diagnoses are made, so ayurvedic treatments are usually undergone alongside and/or after conventional medical approaches. A detailed knowledge of the action of food, spices, and medicinal plants is needed in order to understand their potential influence fully. While societal use of ayurvedic plants and Indian spices is commonplace, without ill effect, the use of more concentrated products made from single plants, often in the form of teas or tablets, is of more concern. The mechanisms by which poly herbal drugs and their extracts act differ in many respects from the actions of single substances or synthetic drugs. Despite the fact that ayurvedic medicines are based on natural herbal materials, their safety depends on their method of administration, taking into account individuals ${ }^{\text {ee }}$ needs and their specific disease conditions. From the above discussion, it is clear that many factors must be considered in prescribing or taking plant-based medicine. A thorough awareness of these plantse $^{\text {ee }}$ actions is needed for their safe selection and consumption. This thesis deals with the importance and development of herbal medicine in the present scenario. Herbal medicines include herbs, herbal preparations and finished herbal products that contain active ingredients, parts of plant, or other materials, or their combination. Traditional use of herbal medicines refers to the long historical use of these medicines. Their use is well established and widely acknowledged to be safe and effective, and accepted by national authorities. They contain pharmacologically active compounds. Furthermore, sometimes these are recommended as dietary supplements or valuable nutraceuticals. The actions of herbal preparation are often different from those of pharmaceuticals containing isolated single compound of the original plant preparation. The current updated status of natural origin used as bioavailability enhancer, immune stimulators, antioxidant and antimicrobials have been elaborated in the form of comprehensive review of literature.

\section{References}

1. McRae J, Yang Q, Crawford R, Palombo E. Review of the methods used for isolating pharmaceutical lead compounds from traditional medicinal plants. The Environmentalist 2007;27(1):165-74.

2. Salim AA, Chin YW, Kinghorn AD. Drug discovery from plants. In Bioactive molecules and medicinal plants. Springer, Berlin, Heidelberg 2008, 1-24.

3. Farnsworth NR, Akerele O, Bingel AS, Soejarto DD, Guo Z. Medicinal plants in therapy. Bulletin of the world health organization 1985;63(6):965-81.

4. Fabricant DS, Farnsworth NR. The value of plants used in traditional medicine for drug discovery. Environmental health perspectives 2001;109(S1):69-75.
5. Butler MS. The role of natural product chemistry in drug discovery. Journal of natural products 2004;67(12):214153.

6. Zareen S. Indian Medicinal Plants and their Uses: An Annotated Bibliography (Doctoral dissertation, Aligarh Muslim University).

7. Dar RA, Shahnawaz M, Qazi PH. General overview of medicinal plants: A review. The Journal of Phytopharmacology 2017;6(6):349-51.

8. World Health Organization. Traditional medicine: growing needs and potential. World Health Organization 2002.

9. Uprety Y, Asselin H, Dhakal A, Julien N. Traditional use of medicinal plants in the boreal forest of Canada: review and perspectives. Journal of ethnobiology and ethnomedicine 2012;8(1):1-4.

10. Lele, RD. Ayurveda (ancient Indian system of medicine) and modern molecular medicine. The Journal of the Association of Physicians of India 1999;47(6):625-628.

11. Das S, Ganguly SN, Mukherjee KK. Fatty acids and phytochemical components of Ipomoea spp. seeds. Natural Product Sciences 1999;5(3):121-3.

12. Park HL, Lee HS, Shin BC, Liu JP, Shang Q, Yamashita H, Lim B. Traditional medicine in China, Korea, and Japan: a brief introduction and comparison. EvidenceBased Complementary and Alternative Medicine 2012, 19.

13. Dubey NK, Kumar R, Tripathi P. Global promotion of herbal medicine: India's opportunity. Current science 2004;86(1):37-41.

14. Singh A, Singh PK. An ethnobotanical study of medicinal plants in Chandauli District of Uttar Pradesh, India. Journal of Ethnopharmacology 2009;121(2):324-9.

15. Saxena HO, Brahmam M. The Flora of Orissa, Regional Research Laboratory and Forest Development Corporation of Orissa, Bhubaneswar 1994-96;1-4.

16. Haines HH. The Botany of Bihar and Orissa, 6 parts London. Botanical Survey of India, Calcutta (Rep. Edn. 1961) 1921-25.

17. World Health Organization. Traditional and Modern Medicine: Harmonizing the Two Approaches: a Report of the Consultation Meeting on Traditional and Modern Medicine: Harmonizing the Two Approaches, 22-26 November 1999, Beijing, China. Manila: WHO Regional Office for the Western Pacific 1999.

18. Pankhurst R. An historical examination of traditional Ethiopian medicine and surgery. Ethiopian Medicine Journal 1965;3:157-72.

19. World Health Organization. Legal status of traditional medicine and complementary. World Health Organization 2001.

20. Gage D. Aloe vera: Nature's soothing healer. Inner Traditions/Bear \& Co 1996.

21. Sahoo H, Mahalik G. Ethnobotanical survey of medicinal plants of Kantapada block of Cuttack district, Odisha, India. International Journal of Biosciences 2020;16(5):284-92.

22. Dash G, Mohanty KK, Sahoo D, Mahalik G, Parida S. Traditional medicinal plants used for the treatment of asthma in Bhubaneswar, Odisha. International Journal of Herbal Medicine 2018;6(5):57-60.

23. Rahman AH, Kabir EZ, Sima SN, Sultana RS, Nasiruddin M, Naderuzzaman AT. Study of an ethnobotany at the village Dohanagar, Naogaon. Journal of Applied Sciences Research 2010;6(9):1466-73. 
24. Kumar PS, Suresh E, Kalavathy S. Review on a potential herb Calotropis gigantea (L.) R. Br. Scholars Academic Journal of Pharmacy 2013;2(2):135-43. 